\title{
Participation in group-based physical activity programmes for adults in Germany and associated factors: data from a nationwide cohort study
}

Susanne Jordan ${ }^{*}$, Susanne Krug and Elena von der Lippe

\begin{abstract}
Background: Characteristics of different participation groups can provide important information to increase participation in group-based physical activity programmes (GPAPs). This study examined four types of participation in GPAPs and the factors that characterised these participant groups.

Methods: The present sample comprised 3219 participants. The analyses were based on data from the 'German Health Interview and Examination Survey for Adults' (t1) conducted in 2009-2011, which included 3959 people who had participated in the 'German National Health Interview and Examination Survey 1998' (t0). The outcome variable was participation in GPAPs, classified in four groups: 'once at t1' (participation only at t1), 'twice' (participation at t0 and t1), 'once at t0' (participation only at t0) and 'no' (no participation). Predictor variables were sex, age, educational level, income, sports activity, self-rated health and counselling for physical activity, measured at t0 and t1. Frequencies with 95\% confidence intervals (Cl) for each group were calculated. Four stepwise logistic regression models with estimated odds ratios (OR) were used to determine group differences.

Results: The largest participant group was 'no' (80.8\%). Among those who participated in GPAPs, the 'once at $\mathrm{t1}^{\prime}$ group was the largest (13.1\%), followed by the 'once at t0' (4.0\%) and 'twice' (2.1\%) groups. 'Once at t1' participation was associated with female sex (OR 2.58), being active in sports (OR 6.59), a high level of education (OR 1.88). If additionally health status and the physician's counselling are included into the models, then having fair/poor/very poor health (OR 1.71) and having had physician counselling on physical activity (OR 2.50) are relevant factors. For 'twice' participation, being female (OR 5.19) and practising sports (OR 4.51) were predictors.

Conclusions: GPAPs should be tailored to build on previous experience of sports activities and to reach men as well as people with low education, groups that have been the least reached. To reach more people and encourage participation in GPAPs, providing opportunity for physician counselling for physical activity may be promising, especially with groups of poorer health.
\end{abstract}

Keywords: Health behaviour change programme, Group programme, Health promotion, Prevention, Training course, Physical activity, Health-related behaviour, Cohort study, German health interview and examination survey for adults (DEGS1)

\footnotetext{
* Correspondence: JordanS@rki.de

Robert Koch Institute, Department of Epidemiology and Health Monitoring, Box 650 61, 13302 Berlin, PO, Germany
}

(c) The Author(s). 2018 Open Access This article is distributed under the terms of the Creative Commons Attribution 4.0 International License (http://creativecommons.org/licenses/by/4.0/), which permits unrestricted use, distribution, and reproduction in any medium, provided you give appropriate credit to the original author(s) and the source, provide a link to the Creative Commons license, and indicate if changes were made. The Creative Commons Public Domain Dedication waiver (http://creativecommons.org/publicdomain/zero/1.0/) applies to the data made available in this article, unless otherwise stated. 


\section{Background}

The promotion of physical activity is a priority for reducing lifestyle-related risk factors for noncommunicable diseases, which comprise the dominating burden of disease in high income countries [1,2]. For Germany, promotion of physical activity is also important because only half of the population (or less, depending on the study referenced) meet the World Health Organization (WHO) recommendations for physical activity [3-5].

Various strategies are used to promote physical activity, including environmental and policy approaches, community-wide and mass media campaigns, and behavioural and social approaches [6, 7]. Different reviews and guidelines based on peer-reviewed studies show that specific interventions can have moderate effects on physical activity (self-reported and measured by cardio-respiratory fitness), although the relationships between intervention components and effects are not clear [7-9]. The WHO noted that in general, strategies that have multiple components and are adjusted to the local context are the most effective [10].

In Germany, health behaviour change programmes are widespread strategies to promote physical activity in adults [11]. These interventions use behavioural training methods, mainly through group-based courses focused on learning and maintaining physical activity practices. They differ from general sports programmes since they are based on a structured approach for health promotion. Our study refers to these programmes as group-based physical activity programmes (GPAPs). Different studies have reported GPAPs are promising for promoting physical activity at a population level. These programmes offer fitness instruction, often at low/no charge to participants, and provide social support through the group context [7]. Providers in Germany include sport clubs, adult education centres, companies, commercial providers (e.g. fitness studios) and statutory health insurance funds (which cover $86 \%$ of the population) [11, 12]. Programmes through health insurance funds also have a statutory order to contribute to reducing health inequality [13]. An evaluation of GPAPs showed they enhanced health behaviour patterns that later diminished in size, but remained higher than before programme participation [14]. These behaviour change effects are also found in comparable interventions from other countries [15].

Participation in GPAPs in Germany has increased about 6-fold in the last decade [16, 17], even considering the changed age structure [17]. However, it is necessary to increase investment in promoting GPAPs, given the low percentage of the population that has achieved physical activity levels necessary for positive health effects. To increase participation in GPAPs at a population level, it is essential to know more about the characteristics of participants and non-participants. In general, factors that influence participation in health behaviour change programmes (including
GPAPs) at the population level in Germany are sex, age, education, social status, general health-related attitudes, social support, health behaviour and health status [17-21]. Therefore the probability of participation in health behaviour change programmes in Germany is increased when population groups are female, of older age, have a middle/ high level of education or social status, live with a partner, are chronically ill or have a low level of self-assessed health status. Participation is also increased in those with pronounced health consciousness or who have healthy lifestyles (e.g. eating three or more portions vegetables and fruits per day, being physically active for 2.5 or more hours a week or being a non-smoker) [17-21].

Current findings about factors influencing participation in GPAPs in Germany are from cross-sectional studies. To date, there are no available data on proportions and factors associated with GPAP participation categories that could inform strategies to increase GPAP participation at the population level. Our study aimed to clarify the proportions of 'once at $\mathrm{t} 1$ ', 'twice,' 'once at $\mathrm{t} 0$ ' and 'no' participation in GPAPs, and determine what distinguishes these groups with regard to demographic and socioeconomic factors, sports behaviour, health status and physician counselling on physical activity. The results will provide data to allow better tailoring of GPAPs for adults to increase GPAPs participation.

\section{Methods}

\section{Study design}

The analyses were based on data from the 'German Health Interview and Examination Survey for Adults' (DEGS1). That survey included 3959 persons who had previously participated in the 'German National Health Interview and Examination Survey 1998' (GNHIES98) (response rate 62\%) [22]. All 6402 GNHIES98 participants were re-invited to join the DEGS1 cohort, and 37\% chose to participate in the DEGS1. Baseline data collection for the GNHIES98 (t0) occurred from October 1997 to March 1999 [23], and for the DEGS1 (t1) from November 2008 to December 2011 [22]. Participants in both surveys were residents of Germany aged 18-79 years. Both surveys were based on two-stage stratified random sampling from local population registers. Data were collected using standardised computer-assisted personal interviews, standardised measurements/tests and a self-administered questionnaire covering physical, mental and social aspects of health. The detailed concept and design of the GNHIES98 and DEGS1 are described elsewhere [22, 24-26].

The DEGS1 was approved by the Federal and State Commissioners for Data Protection and the Charité-Universitätsmedizin Berlin Ethics Committee (No. EA2/047/ 08). All participants provided written informed consent. The GNHIES98 was approved by the Board of the Federal Commissioner for Data Protection Berlin. 


\section{Sample description and participants}

Our analysis included data from adults who participated in both survey waves and were aged $30-79$ years at t1 (18 years and older at baseline/t0). This ensured that participants had opportunity for twice participation in GPAPs at both surveys, as the surveys only included people aged up to 79 years. Furthermore, the analysis was limited to respondents insured under statutory health insurance at follow-up. Statutory health insurance represents more than $86 \%$ of the German population and is a major provider of GPAPs. Participants were asked what type of health insurance they had, and a distinction was made between private and statutory health insurance. Our sample comprised 3219 participants.

\section{Measures}

\section{Outcome variable}

Programme participation In both survey waves, standardised self-administered questionnaires were used to obtain information on GPAPs participation. After a brief introduction, participants were asked whether they had participated in a GPAP during the last 12 months, and if yes, the activity in which they participated $[17,19]$. Both surveys used the same questions with minor variations in wording. At t0 (GNHIES98) the question was: 'There are a number of health promotion programmes organised by health insurance funds, adult education centres, health authorities, private providers or self-help groups focusing on topics like for example diet, physical activity, relaxation and sport or fitness. Have you ever taken part in such measures (courses, exercises, consultations)? Multiple answers allowed'. Various health behaviours were listed: weight reduction, healthy diet, back or spinal gymnastics (back training), relaxation/stress reduction, cessation of smoking, cessation of alcohol abuse, cessation of drug use, other. Response options for each: 'no', 'yes, in the last 12 months' or 'yes, more than 12 months ago' (only the first two categories were included in our analyses). [In German: ,Es gibt eine Reihe von Maßnahmen zur Gesundheitsförderung, die z.B. von Krankenkassen, Volkshochschulen, Gesundheitsämtern, privaten Anbietern oder Selbsthilfegruppen durchgeführt werden und sich beispielsweise mit Ernährung, Bewegung, Entspannung und Sport oder Fitness befassen. Haben Sie an solchen Maßnahmen (Kurse, Übungen, Beratungen) schon einmal teilgenommen? Sie können mehreres ankreuzen': Es wurden verschiedene Gesundheitsverhalten aufgelistet: Gewichtsreduktion, gesunde Ernährung, Rücken- oder Wirbelsäulengymnastik (Rückenschule), Entspannung/Stressbewältigung, Raucherentwöhnung, Alkoholentwöhnung, Drogenentwöhnung, sonstige. Jeweilige Antwortoptionen: ,nein', ,ja, in den vergangenen 12 Monaten' oder ,ja, vor mehr als 12 Monaten' (nur die ersten beiden Kategorien gingen in unsere Analysen ein)] At $t 1$ (DEGS1) the question was: 'There are a number of health promotion programmes organised by various providers and focusing on topics like for example diet, physical activity, relaxation and sport or fitness. Some of these programmes are financed by health insurance funds. Have you taken part in programmes of this kind (courses, exercises, consultations) in the last 12 months? If yes, please indicate which programmes you have attended in the last 12 months and how they have been funded. Multiple answers allowed.' Various health behaviours were listed: weight reduction, healthy diet, gymnastics, relaxation, fitness/recreational sports, relaxation/stress reduction, cessation of smoking, cessation of alcohol abuse, cessation of medication misuse, other. Each could be ticked with: 'yes, in the last 12 months' and how these were financed (the latter was not included in our analyses)]. [In German: ,Es gibt eine Reihe von Maßnahmen zur Gesundheitsförderung, die von verschiedenen Anbietern durchgeführt werden und die sich beispielsweise mit Ernährung, Bewegung, Entspannung und Sport oder Fitness befassen. Teilweise werden solche Maßnahmen von den Krankenversicherungen finanziert. Haben Sie an solchen Maßnahmen (Kurse, Übungen, Beratungen) in den letzten 12 Monaten teilgenommen? ,Wenn ja, bitte geben Sie an, welche Maßnahmen Sie in den letzten 12 Monaten besucht haben und wie diese finanziert waren. Mehrfachantworten möglich'. Es wurden verschiedene Gesundheitsverhalten aufgelistet: Gewichtsreduktion, gesunde Ernährung, Gymnastik, Entspannung/ Stressbewältigung, Fitness/Ausgleichssport, Raucherentwöhnung, Alkoholentwöhnung, Medikamentenentwöhnung, sonstige. Es konnte jeweils angekreuzt werden: ,ja, in den vergangenen 12 Monaten' und wie diese finanziert wurden (letzteres ging nicht in unsere Analysen ein)]. The GNHIES98 response options 'back or spinal gymnastics (back training)' were adapted in the DEGS1 to the current physical activity programme names ('gymnastics' and 'fitness/recreational sport'), which were based on the Guideline Prevention published by the National Association of Statutory Health Insurance Funds [13]. These two options were combined into a 'physical activity' variable. For statistical analyses of GPAP participation, four categories were defined based on GPAP participation/non-participation in both surveys: 'twice' (participation at $\mathrm{t} 0$ and $\mathrm{t} 1$ ), 'once at $\mathrm{t} 1$ ' (no participation at $\mathrm{t} 0$, but participation at $\mathrm{t} 1$ ), 'once at $\mathrm{t} 0$ ' (participation at $\mathrm{t} 0$, but not at $\mathrm{t} 1$ ) and 'no' (no participation at $\mathrm{t} 0$ or $\mathrm{t} 1)$.

\section{Predictor variables}

The selection of variables included in the analyses was therefore based on the results of existing research on factors influencing participation in health behaviour change programmes, with a focus on research in Germany [17, 20,27]. A number of relevant factors were identified: demographic 
characteristics (sex and age), socioeconomic characteristics (educational level), sports behaviour (sports activity), health status (self-assessed) and health system-related enabling factors (e.g. physical activity counselling by a physician). Income was included because GPAPs in Germany are not free of charge. Depending on the provider, programmes require a participation fee, which can be partly reimbursed for courses offered by a statutory health insurance fund [13].

Demographic characteristics Participants' sex and age were included in the analyses. Age was categorised into four groups: 18-29 years, 30-44 years, 45-64 years and 6579 years. Respondents younger than 30 years at $\mathrm{t} 1$ were not included in the analysis, and are therefore not shown in the tables. This was because they did not have an opportunity to participate in GPAP twice, because the age group under study in GNHIES98 (t0) was 18-79 years.

Socioeconomic characteristics Educational level was calculated according to the International Standard Classification of Education, based on participants' school and vocational education grouped into three levels: low, middle and high education $[28,29]$. The need-weighted household net income (net equivalent income) was used as an indicator for income, calculated from household estimated monthly net income and number of individuals living in that household [30]. Missing values for household net income were imputed using a regression model [30, 31]. Based on the general convention on income poverty risk, defined as an income of less than $60 \%$ of the needs-weighted median income, three categories were created: below 60, 60-150\% and above 150\%.

Sports behaviour Sports activity is the health behaviour associated with participation in GPAPs. To assess the frequency of current sports activity, participants were asked how often they practiced sports per week. The last 3 months were given as the reference period. Response categories were: 'no sports activities', 'less than 1 hour per week', 'regularly 1-2 hours per week', 'regularly 2-4 hours per week' and 'regularly more than 4 hours per week'.

Health status Health status was collected by a question on self-rated health that is widely used in surveys and recommended by the WHO [32]. Participants were asked 'How is your health in general?' The five response options were combined into two groups: 'very good/ good' and 'fair/poor/very poor'.

Counselling on physical activity A health system-related enabling factor for participating in health behaviour change programmes was physical activity counselling/ advice from physicians, which appears to be effective in increasing individual physical activity [33-35]. The questionnaire item (self-reported) asked if participants had received physical activity counselling from a primary healthcare physician over the 12 months before the interview. As this question was only asked of persons up to age 64 years, the variable was added in the regression models last, and results are only available for persons up to this age.

\section{Statistical analyses}

Analyses were conducted with a weighting factor to: account for the clustered sampling design; adjust for the distribution of the sample by sex, age, educational status, federal state and type of municipality (to match the German population at $\mathrm{t} 0$ and $\mathrm{t} 1$ ); and adjust for participants' response behaviour [22]. Statistical analyses were performed using survey procedures for complex samples in IBM SPSS v20. Frequencies and 95\% confidence intervals (CI) for the participation groups were calculated. Differences were regarded as statistically significant if the $p$-value (taking into account the weighting and survey design) was less than 0.05 . Given the small number of cases in some subgroups, the analyses could not be stratified by sex. A 'lasagne plot' was used to visualise the types of participation in GPAPs at t0 and $t 1[22,36]$.

Logistic regression models with estimated odds ratios (OR) were used to calculate factors associated with participation groups and determine group differences (reference group 'once at to' for the 'twice' group and reference group 'no' for the group 'once at $t 1$ '). The OR indicated the association between participation in GPAP and a predictor. For example, in the 'once at $\mathrm{t}^{1}$ ' group, an OR of 2.00 for women (reference group men) indicated that the odds for women's GPAP participation at t1 were twice as high as for men compared to women and men who had not participated in GPAP at $\mathrm{t} 0$ and $\mathrm{t} 1$.

Variables were added to the model in a stepwise fashion to identify factors relevant for each group. Data from both $\mathrm{t} 0$ and $\mathrm{t} 1$ were included in the models to show their individual explanatory contributions at the two time points. Model 1 was adjusted for demographic and socioeconomic characteristics at t 0 and $\mathrm{t} 1$ (sex, age, education, income) (but sex and education at $\mathrm{t} 1$ were not included, because they are assumed to be consistent for persons over 30 years). Model 2 comprised Model 1 and sports behaviour at t 0 and $\mathrm{t} 1$. Model 3 included Model 2 plus health status at $\mathrm{t} 0$ and $\mathrm{t} 1$ and Model 4 contained Model 3 and physician physical activity counselling at t0 and 11 . Statistically significant results $(p<0.05)$ are reported in the Results section.

\section{Results}

Sample characteristics

Table 1 shows the characteristics of the survey population at $\mathrm{t} 0$ and $\mathrm{t} 1$ differentiated by demographic (sex and 
Table 1 Sample description $(N=3219)$

\begin{tabular}{|c|c|c|c|c|}
\hline & $\mathrm{n}(\mathrm{t} 0)$ & $\mathrm{n}(\mathrm{t} 1)$ & Total (t1) & Missing (t1) \\
\hline & $\%$ (weighted) & \% (weighted) & N (unweighted) & $\%$ (unweighted) \\
\hline \multicolumn{5}{|l|}{ Demographic characteristics } \\
\hline Sex & & & & 0.0 \\
\hline Women & 52.8 & 52.8 & 1788 & \\
\hline Men & 47.2 & 47.2 & 1431 & \\
\hline Age & & & & 0.0 \\
\hline 18-29 years & $22.4^{\mathrm{a}}$ & - & - & \\
\hline $30-44$ years & 38.6 & 30.6 & 719 & \\
\hline $45-64$ years & 35.8 & 44.4 & 1542 & \\
\hline $65-79$ years & 3.2 & 25.0 & 958 & \\
\hline \multicolumn{5}{|l|}{ Socioeconomic characteristics } \\
\hline Educational level & & & & 0.3 \\
\hline Low & 20.5 & 17.5 & 366 & \\
\hline Middle & 60.4 & 55.8 & 1844 & \\
\hline High & 19.2 & 26.7 & 1000 & \\
\hline Income & & & & 0.0 \\
\hline Below 60\% & 18.4 & 14.4 & 435 & \\
\hline $60-150 \%$ & 64.9 & 65.8 & 2164 & \\
\hline Above $150 \%$ & 16.7 & 19.8 & 620 & \\
\hline \multicolumn{5}{|l|}{ Programme participation } \\
\hline $\begin{array}{l}\text { Participation in a group-based physical } \\
\text { activity programme in the last } 12 \text { months }\end{array}$ & & & & 1.3 \\
\hline Yes & 6.1 & 15.1 & 573 & \\
\hline No & 93.9 & 84.9 & 2605 & \\
\hline \multicolumn{5}{|l|}{ Sports behaviour } \\
\hline Sports activity (in the last 3 months) & & & & 1.0 \\
\hline No sports & 46.4 & 38.9 & 1140 & \\
\hline Less than $1 \mathrm{~h}$ per week & 16.1 & 15.0 & 517 & \\
\hline Regularly $1-2 \mathrm{~h}$ per week & 17.4 & 26.2 & 863 & \\
\hline Regularly 2-4 h per week & 12.4 & 13.3 & 447 & \\
\hline Regularly more than $4 \mathrm{~h}$ per week & 7.7 & 6.6 & 219 & \\
\hline Sports activity aggregated (in the last 3 months) & & & & 1.0 \\
\hline No sports & 46.4 & 38.9 & 1140 & \\
\hline Sports activity per week & 53.6 & 61.1 & 2046 & \\
\hline \multicolumn{5}{|l|}{ Health status } \\
\hline Subjective health status & & & & 0.5 \\
\hline Good/very good & 69.3 & 68.4 & 2211 & \\
\hline Fair/poor/very poor & 30.7 & 31.6 & 991 & \\
\hline \multicolumn{5}{|l|}{ Enabling factor counselling } \\
\hline Physician physical activity counselling ${ }^{b}$ & & & & 30.5 \\
\hline No & 91.1 & 90.6 & 2022 & \\
\hline Yes & 8.9 & 9.4 & 214 & \\
\hline
\end{tabular}


age) and socioeconomic characteristics (education and income). Table 1 also shows the distribution of variables used in further analyses: programme participation, sports activity, self-rated health and counselling for physical activity by a physician. Because of missing values in at least one independent variable, only 3178 respondents could be included in the multivariate analyses.

\section{Descriptive analyses}

GPAP participation increased from $6.1 \%$ (t0) to $15.1 \%$ (t1). Figure 1 illustrates the different participation groups in GPAPs at t0 and t1. The largest group was non-participants, with no participation at t0 or t1 ('no' 80.8, 95\% CI 79.2-82.4). The largest group among GPAPs participants was 'once at $\mathrm{t1}$ ' participants, who started GPAP at t1 (13.1, 95\% CI 11.7-14.5), followed by the 'once at t0' group with participation at to but not at t1 (4.0, 95\% CI 3.4-4.9). The 'twice' group, who participated at both measurement points, was the smallest participant group at $2.1 \%$ (95\% CI 1.7-2.6).

Table 2 presents the characteristics of the four groups at $\mathrm{t} 1$ by demographic and socioeconomic factors, health status, sports behaviour and physical activity counselling by a physician. Most of the potential predictor variables showed significant differences with the outcome variable for one or more group comparisons. What was noticeable was the difference between the three groups that had participated in GPAP and the 'no' group in terms of sports behaviour. The proportion who reported sports behaviour in the last 3 months at the two times was between 73.2 and $91.4 \%$, whereas the proportion for the group without GPAP experience was only $55.3 \%$.

\section{Regression analysis}

The stepwise multivariate logistic regression showed significant associations between predictor and outcome variables for the 'twice' group (reference 'once at to' group) and 'once at t1' group (reference: 'no'). The results are presented in Tables 3 and 4 for each group and model.

For 'once at t1' participants, women had a greater chance of GPAPs participation (Table 3). Depending on the regression model, the OR was about 2.60 (e.g. Model 4: OR 2.69, 95\% CI 1.90-3.80). Sports behaviour showed the largest effect with an OR above 6 (e.g. Model 4: OR 6.46, 95\% CI 4.14-10.10). Compared with low education at t0, a medium or high education level facilitated 'once at t1' participation by 1.80 (95\% CI $1.12-2.91)$ to 2.60 (95\% CI 1.61-4.20), depending on the model and whether the medium or high education group was being examined. In Model 4 educational level showed no significant result anymore. Fair/poor/very poor health status and having had physical activity counselling were associated with smaller chances of being an 'once at t1' participant (e.g. Model 4: OR 1.71, 95\% CI 1.14-2.57 and OR 2.50, 95\% CI 1.64-3.80, respectively). No significant results were found for age and income and all of the factors at $t 0$ with the exception of the educational level (see above).

Being female was the strongest predictor for 'twice' participation, with ORs between 2.88 (95\% CI 1.35-6.13) and 5.19 (95\% CI 1.69-15.96), depending on the model. Income, health status and physical activity counselling had no influence. Age and educational level showed only one association in Model 1 or 3. No further significant results were found for the factors at t0. However, practising sports activity showed an OR between 3.71 (95\% CI 1.50-9.17) and 4.51 (95\% CI 1.34-15.24) compared with not practising sports. The results for 'twice' participation are shown in Table 4.

\section{Discussion}

This study aimed to clarify the proportion and factors characterising 'once at t1', 'twice,' 'once at t0' and 'no' participation in GPAPs using nationwide cohort data from Germany. Regarding participation proportions for the four groups, this study showed that participation in GPAPs increased from about one in 16 people in 1998 to one in seven people in $2009-2011$. However, $80.8 \%$ did not participate in a GPAP in either of the waves, meaning the 'no' group was the largest. This is consistent with expectations, because generally only a certain proportion of the population can be reached with these types of programmes. Among those that had experienced a GPAP, the 'once at t1' participation group (that started a GPAP at the second wave) was the largest; at $13.1 \%$ of participants, it was 6-fold larger than the 'twice' group (2.1\%) and 3-fold larger than the 'once at t0' group (4.0\%). This increase in participation is consistent with parallel developments; for example, fitness studio membership in Germany increased in a comparable period from 4.39 million in 2003 to 6.54 million in 2009 [37]. In addition, sports clubs and adult education centres are increasingly offering health-oriented group courses on physical activity, and have experienced increasing demand and members [38]. This corresponds with the observation that one-third of the adult population (as at 2009) reported they paid attention to adequate physical activity [4]. Our study is the first to show participation rates in GPAP at a population level, based on data that considered previous experience of GPAP participation at an individual level. We also showed that despite the overall increase, the increase in participation rates did not mean that those who participated at t0 participated 10 years later (t1). However, this difference might be explained by the long time interval between the two waves in our study. We do not know whether people in these groups had visited a GPAP in this period. 


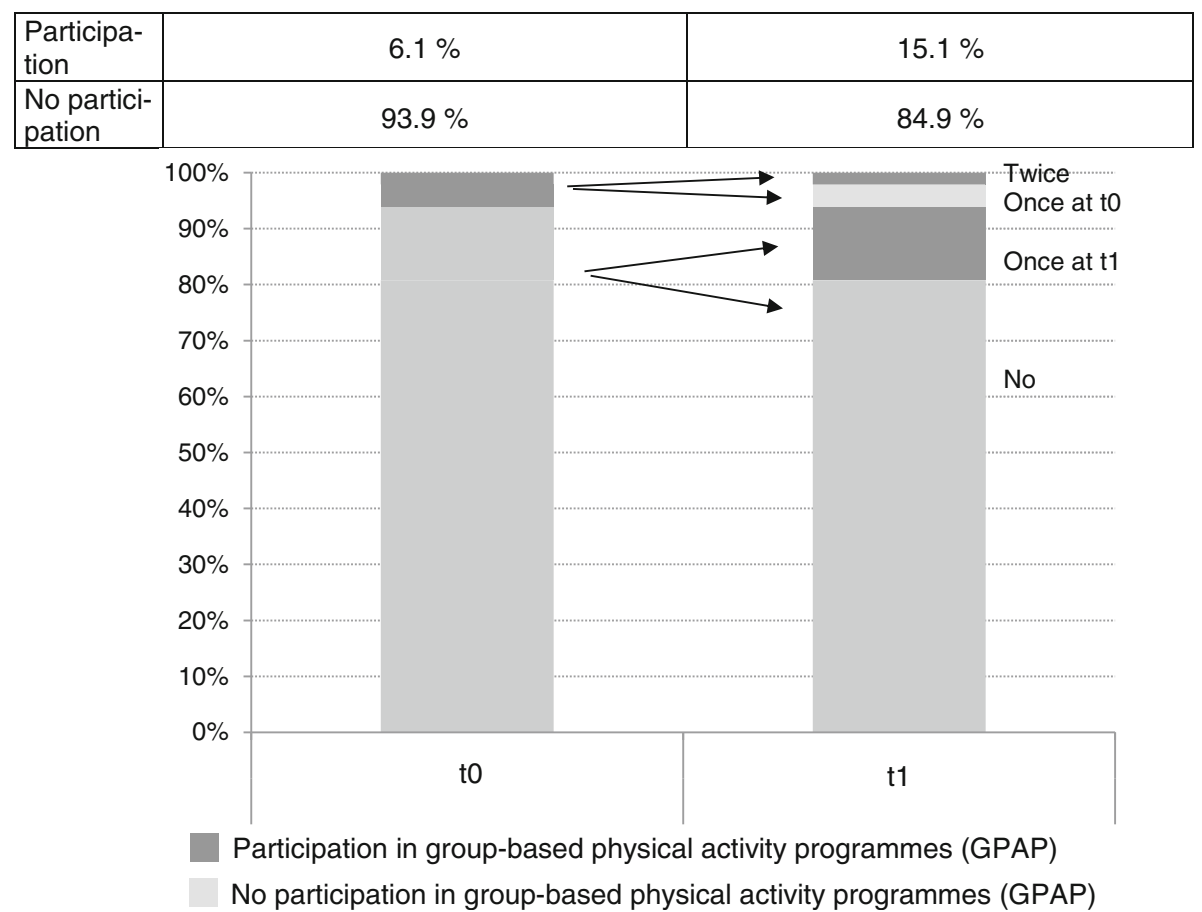

Fig. 1 Plot and distribution table of different participation groups in GPAP in adults at t0 and t1

We observed common characteristics and differences in factors characterising the four participation groups. 'Once at $\mathrm{t} 1$ ' participation was associated with being female, practising sports in the last 3 months, having medium or high level of education, being in fair/poor/ very poor health and having had counselling on physical activity from a physician in the last 12 months. For 'twice' participation, female sex and sports activity in the last 3 months were the relevant factors with significant differences to the reference group. The 'once at t0' group was characterised by female sex and practising sports in the last 3 months. The 'no' group had the highest proportion of sports inactivity compared with the other groups and had an above-average proportion of men. In general, men participate less in prevention programmes $[16,17,39]$ but practice more sports $[4,40]$. Overall, it was noticeable that female sex and sporting behaviour increased the chance of GPAP participation. However, neither age nor income showed relevant differences in terms of participation in GPAPs. Health status and physician counselling on physical activity were only relevant for the 'once at $\mathrm{t} 1$ ' group. Almost none of the factors under study at to were associated with GPAPs participation, age at t0 in Model 1 in 'twice' participation was considered subordinate for the overall interpretation. This was unexpected, particularly with regard to participation in sport at $\mathrm{t} 0$, as other studies showed that previous participation in sport favours the retention/ reactivation of sport or physical activity [41-43]. Our results showed that participation in prevention programmes was, at least in part, influenced by factors other than self-initiated sporting activity.

To our knowledge, the present study of GPAPs participation at the population level is the first of its kind. The results cannot be simply compared with findings from intervention studies focused on promoting physical activity where the influencing factors are known and specifically controlled (e.g. training material, participants of group training, trainer's qualification, objective measurements of participants' attitudes and behaviours). GPAPs participation examined in this study was based on 'realist' or everyday conditions as a type of health services research $[15$, 44], meaning that only self-report for GPAP participation and self-rated information on the studied factors were available. The advantage was that the data realistically reflect the use of the programmes at the population level. However, no data on GPAPs implementation conditions, recruitment, course composition and other details were available, which is often the case with research on health service use. Consequently, for discussion, it was only possible to draw on findings from intervention studies that differed from GPAPs in the present study. Intervention studies are either one-time measures to promote physical activity or research on other health behavioural changes under less realistic conditions. Therefore, these studies did not investigate twice (group) activity participation in two different time points with a long time period, and only analysed motives or mediators for starting participation in 
Table 2 Characteristics of different participation groups in group-based physical activity programmes at t1

\begin{tabular}{|c|c|c|c|c|c|c|}
\hline Participation & $\begin{array}{l}\text { 'Once at t1' } \\
n=479 \\
\%(95 \% \mathrm{Cl})\end{array}$ & $\begin{array}{l}\text { 'Twice' } \\
n=94 \\
\%(95 \% \text { Cl) }\end{array}$ & $\begin{array}{l}\text { 'Once at t0' } \\
n=149 \\
\%(95 \% \mathrm{Cl})\end{array}$ & $\begin{array}{l}\text { 'No' } \\
n=2456 \\
\%(95 \% \text { Cl) }\end{array}$ & $\begin{array}{l}\text { Total } \\
n=3178 \\
\%(95 \% \mathrm{Cl})\end{array}$ & $p$-value \\
\hline Total & $13.1(11.7-14.5)$ & $2.1(1.7-2.6)$ & $4.0(3.4-4.9)$ & $80.8(79.2-82.4)$ & & \\
\hline \multicolumn{7}{|l|}{ Demographic characteristics } \\
\hline \multicolumn{7}{|l|}{ Sex } \\
\hline Women & $68.3(63.4-72.9)$ & $79.9(67.9-88.3)$ & $62.8(53.9-70.8)$ & $48.8(46.4-51.1)$ & $52.5(50.5-54.6)$ & \\
\hline Men & $31.7(27.1-36.6)$ & $20.1(11.7-32.1)$ & $37.2(29.2-46.1)$ & $51.2(48.9-53.6)$ & $47.5(45.4-49.5)$ & 0.000 \\
\hline \multicolumn{7}{|l|}{ Age } \\
\hline 30-44 years & $31.6(26.3-37.4)$ & $10.7(5.7-19.4)$ & $24.2(17.2-32.9)$ & $31.6(28.6-34.7)$ & $30.9(28.1-33.7)$ & \\
\hline 45-64 years & $43.0(37.8-48.4)$ & $52.3(41.2-63.2)$ & $49.6(41.6-57.6)$ & $44.4(41.4-47.4)$ & $44.6(42.0-47.2)$ & \\
\hline $65-79$ years & $25.4(21.3-30.0)$ & $37.0(27.0-48.1)$ & $26.2(19.5-34.2)$ & $24.1(22.1-26.2)$ & $24.6(22.7-26.6)$ & 0.011 \\
\hline \multicolumn{7}{|l|}{ Socioeconomic characteristics } \\
\hline \multicolumn{7}{|l|}{ Educational level } \\
\hline Low & $9.7(6.6-14.1)$ & $16.1(9.0-27.2)$ & $15.4(9.5-24.2)$ & $18.6(16.0-21.5)$ & $17.3(15.0-19.7)$ & \\
\hline Middle & $54.9(49.5-60.2)$ & $48.7(38.4-59.2)$ & $58.4(49.7-66.5)$ & $56.1(53.2-59.0)$ & $55.9(53.3-58.4)$ & \\
\hline High & $35.4(30.3-40.7)$ & $35.2(25.6-46.1)$ & $26.2(18.9-35.1)$ & $25.3(23.0-27.7)$ & $26.8(24.7-29.1)$ & 0.000 \\
\hline \multicolumn{7}{|l|}{ Income } \\
\hline Below 60\% & $9.9(7.0-13.9)$ & $11.7(6.3-20.5)$ & $9.9(5.4-17.2)$ & $15.4(13.3-17.7)$ & $14.4(12.5-16.4)$ & \\
\hline $60-150 \%$ & $66.5(60.4-72.1)$ & $68.1(57.7-76.9)$ & $72.2(63.2-79.8)$ & $65.3(62.9-67.6)$ & $65.8(63.6-68.0)$ & \\
\hline Above $150 \%$ & $23.6(18.7-29.3)$ & $20.3(13.1-30.0)$ & $17.9(11.9-26.0)$ & $19.3(17.1-21.7)$ & $19.8(17.8-22.0)$ & 0.052 \\
\hline \multicolumn{7}{|l|}{ Sports behaviour } \\
\hline \multicolumn{7}{|c|}{ Sports activity aggregated (in the last 3 months) } \\
\hline No sports & $10.8(8.1-14.5)$ & $8.6(4.6-15.5)$ & $26.8(18.8-36.7)$ & $44.7(42.0-47.4)$ & $38.7(36.4-41.1)$ & \\
\hline Sports activity per week & $89.2(85.5-91.9)$ & $91.4(84.5-95.4)$ & $73.2(63.3-81.2)$ & $55.3(52.6-58.0)$ & $61.3(58.9-63.6)$ & 0.000 \\
\hline \multicolumn{7}{|l|}{ Health status } \\
\hline \multicolumn{7}{|l|}{ Subjective health status } \\
\hline Good/very good & $66.5(60.9-71.6)$ & $66.8(57.1-75.3)$ & $65.0(55.9-73.1)$ & $69.3(66.6-71.8)$ & $68.7(66.3-70.9)$ & \\
\hline Fair/poor/very poor & $33.5(28.4-39.1)$ & $33.2(24.7-42.9)$ & $35.0(26.9-44.1)$ & $30.7(28.2-33.4)$ & $31.3(29.1-33.7)$ & 0.515 \\
\hline \multicolumn{7}{|l|}{ Enabling factor } \\
\hline \multicolumn{7}{|c|}{ Physician physical activity counselling } \\
\hline No & $80.5(75.4-84.8)$ & $84.3(72.2-91.7)$ & $91.7(85.0-95.6)$ & $92.3(90.7-93.7)$ & $90.6(89.1-92.0)$ & \\
\hline Yes & 19.5 (15.2-24.6) & $15.7(8.3-27.8)$ & $8.3(4.4-15.0)$ & $7.7(6.3-9.3)$ & $9.4(8.0-10.9)$ & 0.000 \\
\hline
\end{tabular}

$\mathrm{Cl}$, confidence interval

a physical activity programme. Therefore, we have summarised factors relevant for each participant group and discussed the relevance and interpretation of each factor.

\section{Demographic characteristics}

Although the descriptive analysis (Table 2) shows a significant influence of age, age played no role in GPAPs participation. This contrasts with other studies $[45,46]$, but might be explained by other factors in the regression analyses having a stronger influence on participation. Female sex increased the chance of participation compared with the reference group. Consistent with other studies, our results show that males were generally underrepresented [47].

\section{Socioeconomic characteristics}

Different income levels showed no significant differences for participation in GPAPs, consistent with other studies on health behaviour change programmes [20]. In contrast, educational level was associated with once at $\mathrm{t} 1$ participation, with middle and high education levels increasing the chance of starting participation in GPAPs. In general, these courses are dominated by those with middle and high educational levels $[20,48,49]$.

\section{Sports behaviour (sports activity in the last $\mathbf{3}$ months)}

Our study confirmed the observation that behavioural intervention programmes may reach those who need 
Table 3 Factors for 'once at t1' participation in group-based physical activity programmes

\begin{tabular}{|c|c|c|c|c|}
\hline & $\begin{array}{l}\text { Model } 1 \\
\text { Odds ratio }(95 \% \mathrm{Cl})\end{array}$ & $\begin{array}{l}\text { Model } 2 \\
\text { Odds ratio }(95 \% \mathrm{Cl})\end{array}$ & $\begin{array}{l}\text { Model } 3 \\
\text { Odds ratio }(95 \% \mathrm{Cl})\end{array}$ & $\begin{array}{l}\text { Model } 4 \\
\text { Odds ratio }(95 \% \mathrm{Cl})\end{array}$ \\
\hline \multicolumn{5}{|l|}{ Demographic characteristics } \\
\hline \multicolumn{5}{|l|}{ Sex to } \\
\hline Women & $\mathbf{2 . 5 5 * * *}(1.98-3.29)$ & $\mathbf{2 . 5 4} * * *(1.95-3.32)$ & $\mathbf{2 . 5 8} * * *(1.98-3.38)$ & $\mathbf{2 . 6 9 * * *}(1.90-3.80)$ \\
\hline Men & Ref. & Ref. & Ref. & Ref. \\
\hline \multicolumn{5}{|l|}{ Age to } \\
\hline 18-29 years & $0.99(0.57-1.72)$ & $0.92(0.52-1.61)$ & $0.99(0.55-1.78)$ & $0.96(0.53-1.74)$ \\
\hline $30-44$ years & Ref. & Ref. & Ref. & Ref. \\
\hline 45-64 years & $1.02(0.68-1.54)$ & $1.08(0.71-1.64)$ & $1.06(0.69-1.61)$ & $1.15(0.74-1.81)$ \\
\hline $65-79$ years & $0.40(0.15-1.08)$ & $0.52(0.18-1.50)$ & $0.46(0.16-1.35)$ & - \\
\hline \multicolumn{5}{|l|}{ Age t1 } \\
\hline $30-44$ years & Ref. & Ref. & Ref. & Ref. \\
\hline $45-64$ years & $0.92(0.57-1.48)$ & $0.85(0.52-1.39)$ & $0.83(0.49-1.40)$ & $0.77(0.46-1.30)$ \\
\hline $65-79$ years & $1.18(0.61-2.28)$ & $1.15(0.58-2.26)$ & $1.13(0.56-2.31)$ & - \\
\hline \multicolumn{5}{|l|}{ Socioeconomic characteristics } \\
\hline \multicolumn{5}{|l|}{ Educational level to } \\
\hline Low & Ref. & Ref. & Ref. & Ref. \\
\hline Middle & $1.82 * *(1.18-2.80)$ & $1.41(0.92-2.16)$ & $1.47(0.96-2.26)$ & $1.19(0.70-2.04)$ \\
\hline High & $2.60 * * *(1.61-4.20)$ & $1.80 *(1.12-2.91)$ & $1.88^{*}(1.16-3.04)$ & $1.59(0.85-2.97)$ \\
\hline \multicolumn{5}{|l|}{ Income to } \\
\hline Below 60\% & Ref. & Ref. & Ref. & Ref. \\
\hline $60-150 \%$ & $1.12(0.72-1.72)$ & $1.12(0.73-1.73)$ & $1.12(0.74-1.70)$ & $1.19(0.71-1.98)$ \\
\hline Above $150 \%$ & $1.34(0.84-2.15)$ & $1.26(0.80-1.98)$ & $1.27(0.82-1.99)$ & $1.01(0.55-1.85)$ \\
\hline \multicolumn{5}{|l|}{ Income t1 } \\
\hline Below 60\% & Ref. & Ref. & Ref. & Ref. \\
\hline $60-150 \%$ & $1.44(0.94-2.21)$ & $1.27(0.82-1.98)$ & $1.37(0.89-2.10)$ & $1.22(0.73-2.04)$ \\
\hline Above $150 \%$ & $1.52(0.90-2.57)$ & $1.17(0.69-1.98)$ & $1.30(0.78-2.17)$ & $1.21(0.66-2.22)$ \\
\hline \multicolumn{5}{|l|}{ Sports behaviour } \\
\hline \multicolumn{5}{|c|}{ Sports activity aggregated (in the last 3 months) to } \\
\hline No sports & & Ref. & Ref. & Ref. \\
\hline Sports activity per week & & $\begin{array}{l}1.00 \\
(0.78-1.28)\end{array}$ & $\begin{array}{l}1.04 \\
(0.82-1.33)\end{array}$ & $\begin{array}{l}1.08 \\
(0.78-1.50)\end{array}$ \\
\hline \multicolumn{5}{|c|}{ Sports activity aggregated (in the last 3 months) t1 } \\
\hline No sports & & Ref. & Ref. & Ref. \\
\hline Sports activity per week & & $6.20 * * *(4.20-9.14)$ & $6.59 * * *(4.44-9.80)$ & $6.46^{* * *}(4.14-10.10)$ \\
\hline \multicolumn{5}{|l|}{ Health status } \\
\hline \multicolumn{5}{|l|}{ Subjective health status to } \\
\hline Good/very good & & & Ref. & Ref. \\
\hline Fair/poor/very poor & & & $0.78(0.54-1.13)$ & $0.82(0.52-1.28)$ \\
\hline \multicolumn{5}{|l|}{ Subjective health status t1 } \\
\hline Good/very good & & & Ref. & Ref. \\
\hline Fair/poor/very poor & & & $1.94 * * *(1.42-2.66)$ & $1.71 * *(1.14-2.57)$ \\
\hline
\end{tabular}


Table 3 Factors for 'once at $\mathrm{t}^{\prime}$ ' participation in group-based physical activity programmes (Continued)

\begin{tabular}{|c|c|c|c|c|}
\hline & $\begin{array}{l}\text { Model } 1 \\
\text { Odds ratio }(95 \% \mathrm{Cl})\end{array}$ & $\begin{array}{l}\text { Model } 2 \\
\text { Odds ratio }(95 \% \mathrm{Cl})\end{array}$ & $\begin{array}{l}\text { Model } 3 \\
\text { Odds ratio }(95 \% \mathrm{Cl})\end{array}$ & $\begin{array}{l}\text { Model } 4 \\
\text { Odds ratio (95\% Cl) }\end{array}$ \\
\hline \multicolumn{5}{|c|}{ Enabling factor } \\
\hline \multicolumn{5}{|c|}{ Physician physical activity counselling to } \\
\hline No & & & & Ref. \\
\hline Yes & & & & $0.99(0.64-1.51)$ \\
\hline \multicolumn{5}{|c|}{ Physician physical activity counselling t1 } \\
\hline No & & & & Ref. \\
\hline Yes & & & & $\mathbf{2 . 5 0 * * * ( 1 . 6 4 - 3 . 8 0 )}$ \\
\hline Nagelkerke & 0.065 & 0.164 & 0.175 & 0.177 \\
\hline
\end{tabular}

them the least $[45,50]$. For example, people who twice participated in a web-based health promotion programme had healthier lifestyles than people who participated only once [45]. One study found that in repeaters, the motives for sporting activity were more pronounced [51]. In our study, sports activity in the last 3 months was relevant for all participant groups, especially the 'once at t1' and 'twice' groups, where sports activity was a strong predictor for participation in GPAPs. 'Once at t0' participation might be attributable to several reasons. The end of a sports programme (GPAP) is a critical point (decision-making moment) and often means the end of that activity. Other studies have shown that people who dropped out of a sports programme often found the programme, the trainer, the location or their current living situation less appropriate that those who continued participation [51]. Sports activity might indicate that starting another sports activity (e.g. a fitness studio) was a reason for 'once at to' group [51,52]. Some GPAPs explicitly state they serve to stimulate physical activity in general (for example courses offered by the statutory health insurance funds) [13]. In general, sport participation increased the chance of participating in GPAPs, meaning GPAPs reach people who are already active. Therefore, there is a risk that GPAPs will increase health inequalities (prevention dilemma). However, they are also able to motivate people who have been physically active as a result of physicians' counselling.

\section{Health status}

Health status was only relevant for the 'once at t1' group. Contrary to other studies, a worse state of health was not accompanied by less physical activity among 'once at t0' participants $[43,53]$. People with fair/poor/very poor health had a greater chance of starting a GPAP than those with good/very good health. An individual perception of a poorer state of health may motivate people to improve their health behaviour, for example increasing physical activity. This is consistent with other studies that investigated how people with chronic illnesses can be reached to increase physical activity to reduce the risk of secondary illnesses (e.g. diabetes type 2 or cardiovascular disease) [54]. A GPAP seems a helpful motivator for starting physical activity, especially if a doctor has advised such activity [55].

\section{Counselling on physical activity}

Physician counselling on physical activity was a health system-related enabling factor that was only relevant for the 'once at $\mathrm{tl}^{\prime}$ ' group. In general, counselling or advice for brief physical activity (5-20 min) through primary care aims to raise consciousness of the relevance of physical activity and encourage people to increase/maintain their activity level [56]. Consistent with other studies [33-35, 57], we found physical activity counselling was effective in motivating and supporting people to start physical activity [56]. This may also be a cost-effective intervention that to improve physical activity, even at 12 months following the intervention [33]. However, there may be a risk that physician counselling may lead to widening health inequalities if people from vulnerable groups do not use primary care services [58].

\section{Strength and limitations}

A strength of this study was that it is the first to examine the population groups and factors that affect participation ('once at $\mathrm{t} 1$ ', 'twice,' 'once at $\mathrm{t} 0$ ' and 'no') in GPAPs at two waves over a long time span. However, a weakness of our study design was that there was almost no information about the health status, sports behaviour or preventive activities between the two waves, and no information about the circumstances of the GPAPs visited by participants. It should also be noted that our study only included a limited number of factors, namely those that were expected to be directly related to participation 
Table 4 Factors for 'twice' participation in group-based physical activity programmes

\begin{tabular}{|c|c|c|c|c|}
\hline & $\begin{array}{l}\text { Model } 1 \\
\text { Odds ratio (95\% Cl) }\end{array}$ & $\begin{array}{l}\text { Model } 2 \\
\text { Odds ratio }(95 \% \text { Cl) }\end{array}$ & $\begin{array}{l}\text { Model } 3 \\
\text { Odds ratio }(95 \% \mathrm{Cl})\end{array}$ & $\begin{array}{l}\text { Model } 4 \\
\text { Odds ratio }(95 \% \mathrm{Cl})\end{array}$ \\
\hline \multicolumn{5}{|l|}{ Demographic characteristics } \\
\hline \multicolumn{5}{|l|}{ Sex to } \\
\hline Women & $\mathbf{3 . 0 0} * *(1.45-6.21)$ & $\mathbf{2 . 8 8 * *}(1.35-6.13)$ & $3.05 * *(1.42-6.57)$ & $\mathbf{5 . 1 9 * *}(1.69-15.96)$ \\
\hline Men & Ref. & Ref. & Ref. & Ref. \\
\hline \multicolumn{5}{|l|}{ Age to } \\
\hline 17-29years & $0.91(0.16-5.12)$ & $0.92(0.16-5.22)$ & $1.04(0.19-5.79)$ & $1.18(0.20-7.13)$ \\
\hline 30-44 years & Ref. & Ref. & Ref. & Ref. \\
\hline 45-64 years & $\mathbf{2 . 5 9} *(1.03-6.51)$ & $2.36(0.94-5.89)$ & $2.29(0.88-5.92)$ & $2.61(0.87-7.84)$ \\
\hline $65-79$ years & $2.57(0.18-37.22)$ & $1.59(0.11-22.68)$ & $1.47(0.10-20.98)$ & - \\
\hline \multicolumn{5}{|l|}{ Age t1 } \\
\hline 30-44 years & Ref. & Ref. & Ref & Ref \\
\hline $45-64$ years & $1.38(0.31-6.12)$ & $1.43(0.31-6.52)$ & $1.58(0.35-7.14)$ & $1.69(0.35-8.12)$ \\
\hline $65-79$ years & $1.06(0.17-6.50)$ & $1.33(0.22-7.94)$ & $1.57(0.26-9.60)$ & - \\
\hline \multicolumn{5}{|l|}{ Socioeconomic characteristics } \\
\hline \multicolumn{5}{|l|}{ Educational level to } \\
\hline Low & Ref. & Ref. & Ref. & Ref. \\
\hline Middle & $1.21(0.50-2.93)$ & $1.37(0.54-3.44)$ & $1.46(0.61-3.54)$ & $2.75(0.72-10.61)$ \\
\hline High & $2.50(0.95-6.61)$ & $2.56(0.90-7.31)$ & $2.87^{*}(1.02-8.13)$ & $4.17(0.91-19.16)$ \\
\hline \multicolumn{5}{|l|}{ Income to } \\
\hline Below 60\% & Ref. & Ref. & Ref. & Ref. \\
\hline $60-150 \%$ & $0.73(0.28-1.90)$ & $0.54(0.22-1.35)$ & $0.56(0.22-1.38)$ & $0.28(0.08-1.00)$ \\
\hline Above $150 \%$ & $0.82(0.26-2.59)$ & $0.68(0.21-2.18)$ & $0.65(0.20-2.08)$ & $0.39(0.08-1.97)$ \\
\hline \multicolumn{5}{|l|}{ Income t1 } \\
\hline Below 60\% & Ref. & Ref. & Ref. & Ref. \\
\hline $60-150 \%$ & $0.72(0.26-1.99)$ & $0.80(0.28-2.30)$ & $0.69(0.24-1.98)$ & $0.69(0.17-2.74)$ \\
\hline Above $150 \%$ & $0.79(0.26-2.41)$ & $0.89(0.29-2.77)$ & $0.79(0.24-2.60)$ & $1.3(0.30-5.73)$ \\
\hline \multicolumn{5}{|l|}{ Sports behaviour } \\
\hline \multicolumn{5}{|c|}{ Sports activity aggregated (in the last 3 months) to } \\
\hline No sports & & Ref. & Ref. & Ref. \\
\hline Sports activity per week & - & $1.50(0.67-3.35)$ & $1.44(0.64-3.25)$ & $1.73(0.48-6.23)$ \\
\hline \multicolumn{5}{|c|}{ Sports activity aggregated (in the last 3 months) t1 } \\
\hline No sports & & Ref. & Ref & Ref. \\
\hline Sports activity per week & & $3.71 * *(1.50-9.17)$ & $\mathbf{3 . 8 6 * *}(1.51-9.82)$ & $\mathbf{4 . 5 1 * ( 1 . 3 4 - 1 5 . 2 4 )}$ \\
\hline \multicolumn{5}{|l|}{ Health status } \\
\hline \multicolumn{5}{|l|}{ Subjective health status to } \\
\hline Good/very good & & & Ref. & Ref. \\
\hline Fair/poor/very poor & & & $0.78(0.40-1.52)$ & $0.54(0.19-1.56)$ \\
\hline \multicolumn{5}{|l|}{ Subjective health status $t 1$} \\
\hline Good/very good & & & Ref. & Ref. \\
\hline Fair/poor/very poor & & & $1.21(0.61-2.41)$ & $1.71(0.56-5.23)$ \\
\hline
\end{tabular}


Table 4 Factors for 'twice' participation in group-based physical activity programmes (Continued)

\begin{tabular}{|c|c|c|c|c|}
\hline & $\begin{array}{l}\text { Model } 1 \\
\text { Odds ratio }(95 \% \text { Cl) }\end{array}$ & $\begin{array}{l}\text { Model } 2 \\
\text { Odds ratio }(95 \% \mathrm{Cl})\end{array}$ & $\begin{array}{l}\text { Model } 3 \\
\text { Odds ratio }(95 \% \mathrm{Cl})\end{array}$ & $\begin{array}{l}\text { Model } 4 \\
\text { Odds ratio }(95 \% \mathrm{Cl})\end{array}$ \\
\hline \multicolumn{5}{|l|}{ Enabling factor } \\
\hline \multicolumn{5}{|c|}{ Physician physical activity counselling to } \\
\hline No & & & & Ref. \\
\hline Yes & & & & $1.36(0.49-3.77)$ \\
\hline \multicolumn{5}{|c|}{ Physician physical activity counselling t1 } \\
\hline No & & & & Ref. \\
\hline Yes & & & & $3.15(0.98-10.09)$ \\
\hline Nagelkerke & 0.137 & 0.196 & 0.202 & 0.288 \\
\hline
\end{tabular}

in GPAPs. Further research on factors related to twice or one-time participation in GPAPs should integrate additional factors into the analyses, such as body weight (overweight and obesity), smoking habits, fruit and vegetable consumption $[45,55]$ or health-related quality of life, self-efficacy and enjoyment [48], all of which influenced participation in health behaviour change programmes in other studies.

Regarding the GPAP question, the response options at to and $\mathrm{t} 1$ are not fully identical, so that the comparability is not perfect and might have led to a small bias (with an underestimation at $t 0$ of participants). In contrast to $t 1$, the option fitness courses was not offered as an answer due to the fact that at this time these were not offered as health promotion programmes. However, there is no indication that a possible underreporting bias at t0 systematically skews the result with regard to the analysed influencing factors. The partly different wording of answer options was adapted to typical names and contents of GPAP during each measurement. This should make it easier for respondents to identify the programmes in which they actually took part in.

With regard to the association between GPAP and sporting activity, it should be noted that it cannot be completely ruled out that respondents might have considered GPAP participation as sporting activity. However, cross tabulation between sport activity and GPAP participation for GNHIES98 and DEGS1 showed that there were enough cases of respondents in the GPAP, who participate in GPAP and did not practice sport. Another aspect is that participation in GPAP refers to the last 12 months and sports activity refers to the last three months. We assume, thus, that the overlapping (people who said they did sport did so because of participation in GPAP) is relative small.

A limitation of the observed factors affects our conclusions based on the analyses of Model 4. With the inclusion of the enabling factor (physician physical activity counselling), only data from persons up to age 64 years could be inserted into the regression model because this information was only obtained from people aged up to 64 years. However, as counselling by a physician was identified as important in other studies, we integrated this variable into the model. Additionally, it must be considered that there could be a relation between the worse health status and a contact with a physician which would lead to a counselling. Unfortunately, with the current analysis we are not able to control for this.

\section{Conclusions}

Various studies have shown that GPAP participation in Germany has increased over the last decade. However, our study is the first to provide insights about GPAP participation considering previous individual-level GPAP experience. Based on data from these two separate time points, this study specifies the proportions of people who participated once or twice in such programmes, those who are not reached, and clarifies how these groups differed. Measures to increase GPAPs participation should consider how 'once at $\mathrm{t}^{\prime}$ ' and 'twice' participation vary in terms of factors that influence or motivate participation. A small but growing proportion of the population participates in GPAPs. However, only certain population groups are reached by such programmes (e.g. females and those practising sports). Various steps are needed to achieve further effects and greater participation of groups at the population level that have not participated in GPAPs and are not 'sportive'. It is not sufficient to simply expand programmes that have proven to be effective under research conditions [59]. As our study shows, it is important to tailor programmes to reach groups of both sexes and different levels of physical activity experience. In addition, programmes should be tailored to different groups in terms of their previous experience with 
GPAPs, and consider motivations and supportive/constraining conditions underlying participation in GPAPs and physical activity. This could be achieved by tailoring GPAPs to address potential participants' readiness for change status or by considering the special needs of targeted groups or individual participants [9]. To get more people into GPAPs and physical activity, it seems promising to provide physical activity counselling for people with a poorer state of health and who present to primary care. There are positive reports from other countries [57] and the new Prevention Act introduced in 2015 in Germany promotes physician counselling [60]. Furthermore, our findings are also useful for other countries, as the non-communicable disease crisis is an overarching problem [1].

GPAPs should be tailored to build on previous experience of sports activities and to reach men as well as people with low education, groups that have been the least reached. GPAPs should also be complemented by policy and environmental interventions that support active living across society $[9,61,62]$. To upscale the effects and dissemination of GPAPs, it is necessary to address the contexts for healthy lifestyles with supportive health policies and enabling environments [59]. Furthermore, to achieve these goals it is necessary to reach the most disadvantaged populations through GPAPs and in related research [33]. Future research should concentrate on factors influencing longitudinal and long-term effects of GPAPs, information that is needed for research in promoting physical activity [63].

\section{Abbreviations \\ Cl: Confidence interval; DEGS1: German Health Interview and Examination Survey for Adults 2008-11; GNHIES98: German National Health Interview and Examination Survey 1997-99; GPAPs: Group-based physical activity programmes; OR: Odds ratios; WHO: World Health Organization}

\section{Acknowledgements}

We would like to thank the study participants who responded to the survey and all of our colleagues from the Robert Koch Institute who helped conduct the DEGS1 and GNHIES98 survey. We also thank Audrey Holmes, MA, from Edanz Group (www.edanzediting.com/) for editing a draft of this manuscript.

\section{Funding}

The health surveys (GNHIES98 and DEGS1) were funded by the Federal Ministry of Health Germany. The authors received no funding for this study.

\section{Availability of data and materials}

The DEGS1 and GNHIES98 data sets underlying the findings are archived in the 'Health Monitoring' Research Data Centre at the Robert Koch Institute (RKI) and can be accessed by all interested researchers (as public use file on request). On-site access to the data set is possible at the Secure Data Center of the RKI's 'Health Monitoring' Research Data Centre. Requests should be submitted to the 'Health Monitoring' Research Data Centre, Robert Koch Institute, Berlin, Germany (e-mail: fdz@rki.de).

\section{Authors' contributions}

SJ wrote the manuscript and EvdL and SK critically revised it. SJ, SK and EvdL conceptualised the present study, developed the analysis plan and interpreted the results. SK and EvdL conducted the statistical analysis. All authors read and approved the final manuscript.

\section{Ethics approval and consent to participate}

The DEGS1 was approved by the Federal and State Commissioners for Data Protection and the Charité-Universitätsmedizin Berlin Ethics Committee (No. EA2/047/08). All participants provided informed written consent. The GNHIES98 was approved by the Board of the Federal Commissioner for Data Protection Berlin.

\section{Consent for publication}

Not applicable.

\section{Competing interests}

The authors declare that they have no competing interests.

\section{Publisher's Note}

Springer Nature remains neutral with regard to jurisdictional claims in published maps and institutional affiliations.

Received: 27 March 2018 Accepted: 20 November 2018

Published online: 12 December 2018

\section{References}

1. Beaglehole R, Bonita R, Horton R, Adams C, Alleyne G, Asaria P, et al. Priority actions for the non-communicable disease crisis. Lancet. 2011;377:1438-47.

2. Plass D, Vos T, Hornberg C, Scheidt-Nave C, Zeeb H, Kramer A. Trends in disease burden in Germany: results, implications and limitations of the global burden of disease study. Dtsch Arztebl Int. 2014;111:629-38. https:// doi.org/10.3238/arztebl.2014.0629.

3. Finger JD, Mensink GBM, Lange C, Manz K. Health-enhancing physical activity during leisure time among adults in Germany. Journal of Health Monitoring, 2017. 2:35-42. https://doi.org/10.17886/RKI-GBE-2017-040.

4. Krug S, Jordan S, Mensink G, Müters S, Finger J, Lampert T. Physical activity: results of the German Health Interview and Examination Survey for Adults (DEGS1). [Körperliche Aktivität. Ergebnisse der Studie zur Gesundheit Erwachsener in Deutschland (DEGS1)]. Bundesgesundheitsbl Gesundheitsforsch Gesundheitsschutz. 2013;56:765-71.

5. Robert Koch Institute. Physical activity. Fact sheet on GEDA 2012: Results of the study "German Health Update 2012". [Körperliche Aktivität. Faktenblatt zU GEDA 2012: Ergebnisse der Studie "Gesundheit in Deutschland aktuell 2012"]. Berlin: RKl; 2014.

6. Conn VS, Hafdahl A, Phillips $\amalg$, Ruppar TM, Chase JA. Impact of physical activity interventions on anthropometric outcomes: systematic review and meta-analysis. J Prim Prev. 2014;35:203-15.

7. Heath GW, Parra DC, Sarmiento OL, Andersen LB, Owen N, Goenka S, et al. Evidence-based intervention in physical activity: lessons from around the world. Lancet. 2012;380:272-81.

8. Foster C, Hillsdon M, Thorogood M, Kaur A, Wedatilake T. Interventions for promoting physical activity. Cochrane Database Syst Rev. 2005;1:CD003180. https://doi.org/10.1002/14651858.CD003180.pub2.

9. Centers for Disease Control and Prevention (CDC). Strategies to prevent obesity and other chronic diseases: the CDC guide to strategies to increase physical activity in the community. Atlanta: US Department of health and human services; 2011.

10. World Health Organization (WHO). Interventions on diet and physical activity: what works. Summary report. Geneva: WHO; 2009.

11. Jordan S, Weiss M, Krug S, Mensink GB. Overview of primary prevention measures to promote physical activity in Germany. (Überblick über primärpräventive Maßnahmen zur Förderung von körperlicher Aktivitat in Deutschland). Bundesgesundheitsbl Gesundheitsforsch Gesundheitsschutz. 2012;55:73-81

12. Rosenbrock R, Michel C. Primary prevention. Elements for a systematic health care protection. [Primäre Prävention. Bausteine für eine systematische Gesundheitssicherung]. Berlin: Medizinische Wissenschaftliche Verlagsgesellschaft; 2007.

13. Arbeitsgemeinschaft der Spitzenverbände der Krankenkassen, editor. Guideline Prevention. Common and standardised fields of action and criteria of the central associations of the health insurance funds for the implementation of $\S \S 20$ and 20a SGB V of 21 June 2000 as amended on 2 June 2008. [Leitfaden Prävention. Gemeinsame und einheitliche Handlungsfelder und Kriterien der Spitzenverbände der Krankenkassen zur Umsetzung von $\S \S 20$ und 20a SGB V vom 21. Juni 2000 in der Fassung 
vom 2. Juni 2008]. Bonn, Frankfurt am Main: KomPart Verlagsgesellschaft; 2008.

14. Kliche T, Schreiner-Kürten K, Wanek V, Koch U. Health promotion effectiveness: testing the German statutory health insurance agencies evaluation system in health promotion, and preliminary findings from 212 health training courses. [Gesundheitswirkungen von Prävention: Erprobung des Evaluationssystems der Krankenkassen im Individualansatz und erste Befunde aus 212 Gesundheitskursen]. Gesundheitswesen. 2011;73:258-63.

15. Harden SM, McEwan D, Sylvester BD, Kaulius M, Ruissen G, Burke SM, et al. Understanding for whom, under what conditions, and how group-based physical activity interventions are successful: a realist review. BMC Public Health. 2015;15:958.

16. Medizinischer Dienst des Spitzenverbandes Bund der Krankenkassen (MDS), GKV-Spitzenverband, editors. Prevention report 2010: Services of the statutory health insurance fund: primary prevention and workplace health promotion. Reporting year 2009. [Präventionsbericht 2010. Leistungen der gesetzlichen Krankenversicherung: Primärprävention und betriebliche Gesundheitsförderung. Berichtsjahr 2009]. Berlin: GKV-Spitzenverband; 2010.

17. Jordan S, von der Lippe E. Participation in health behaviour change programmes. Results of the German Health Interview and Examination Survey for Adults (DEGS1). [Teilnahme an verhaltenspräventiven Maßnahmen. Ergebnisse der Studie zur Gesundheit Erwachsener in Deutschland (DEGS1)]. Bundesgesundheitsbl Gesundheitsforsch Gesundheitsschutz 2013;56:1-7; doi: https://doi.org/10.1007/s00103-013-1664-y.

18. Kirschner W, Radoschewski M, Kirschner R. § 20 SGB V. Health promotion, disease prevention-Study for the implementation by the health insurance funds. [ $\$ 20$ SGB V. Gesundheitsförderung, Krankheitsverhütung - Untersuchung zur Umsetzung durch die Krankenkassen]. Sankt Augustin: Asgard Verlag; 1995.

19. Kahl H, Holling H, Kamtsiuris P. Utilization of health screening studies and measures for health promotion. [Inanspruchnahme von Früherkennungsuntersuchungen und Maßnahmen zur Gesundheitsförderung]. Gesundheitswesen. 1999;61:S163-8.

20. Jordan S, von der Lippe E. Prevention Programmes-who takes part? GBE kompakt. 2012;3:5 https:/wwww.rki.de/EN/Content/Health_Monitoring/Health_ Reporting/GBEDownloadsK/2012_5_prevention.html?nn=3321752. Accessed 15 Jan 2017.

21. Ladebeck N, March S, Swart E. Utilisation of individual health promotion benefits for employees: results of the lidA-study. [Inanspruchnahme von Leistungen zur individuellen Gesundheitsförderung bei Erwerbstätigen: Ergebnisse der lidA-Studie]. Präv Gesundheitsf. 2015;10:22-7.

22. Kamtsiuris $P$, Lange M, Hoffmann R, Schaffrath Rosario A, Dahm S, Kurth BM. The first wave of the German health interview and examination survey for adults (DEGS1): sample design, response, weighting and representativeness. [die erste Welle der Studie zur gesundheit Erwachsener in Deutschland (DEGS1): Stichprobendesign, response, Gewichtung und Repräsentativität]. Bundesgesundheitsbl Gesundheitsforsch Gesundheitsschutz. 2013;56:620-30.

23. Thefeld W, Stolzenberg H, Bellach BM. The Federal Health Survey: response, composition of participants, and non-respondener analysis. [BundesGesundheitssurvey: Response, Zusammensetzung der Teilnehmer und Nonresponder-Analyse]. Gesundheitswesen. 1999;61:S57-61.

24. Gößwald A, Lange M, Kamtsiuris P, Kurth B-M. DEGS: German health interview and examination survey for adults. A nationwide cross-sectional and longitudinal study within the framework of health monitoring conducted by the Robert Koch Institute. [DEGS: Studie zur Gesundheit Erwachsener in Deutschland: Bundesweite Quer- und Längsschnittstudie im Rahmen des Gesundheitsmonitorings des Robert Koch-Instituts]. Bundesgesundheitsbl Gesundheitsforsch Gesundheitsschutz. 2012;55:775-80.

25. Scheidt-Nave C, Kamtsiuris P, Gößwald A, Hölling H, Lange M, Busch AM, et al. German health interview and examination survey for adults (DEGS)design, objectives and implementation of the first data collection wave. BMC Public Health. 2012;12:730.

26. Bellach B-M, Knopf H, Thefeld W. The German health survey. 1997/98. [Der Bundes-Gesundheitssurvey 1997/98]. Gesundheitswesen. 1998;60:S59-68.

27. Gabrys L, Jordan S, Schlaud M. Prevalence and temporal trends of physical activity counselling in primary health care in Germany from 1997-1999 to 2008-2011. Int J Behav Nutr Phys Act. 2015;12:136.

28. Schroedter J, Lechert Y, Lüttinger P. Implementation of the ISCED-1997 education scale for the 1970 census, the microcensus supplementary survey 1971 and the microcensors 1976-2004. [Die Umsetzung der Bildungsskala ISCED-1997 für die Volkszählung 1970, die Mikrozensus-Zusatzerehebung 1971 und die Mikrozensen 1976-2004 (Nersion). ZUMA-Methodenbericht 2006/08]. 2006. http://www.gesis. org/fileadmin/upload/forschung/publikationen/gesis_reihen/gesis_ methodenberichte/2006/06_08_Schroedter.pdf. Accessed 9 Jun 2010.

29. United Nations Educational, Scientific and Cultural Organization (UNESCO). International standard classification of education (ISCED). Montreal: UNESCO; 1997.

30. Lampert T, Kroll L, Muters S, Stolzenberg H. Measurement of socioeconomic status in the German health interview and examination survey for adults (DEGS1). Bundesgesundheitsblatt, Gesundheitsforschung, Gesundheitsschutz. 2013;56:631-6.

31. Lampert T, Kroll L. Poverty and health. [Armut und gesundheit]. GBE kompakt. 2010;1:5. https://www.rki.de/EN/Content/Health_Monitoring/ Health_Reporting/GBEDownloadsK/2010_5_poverty_health.pdf?_blob= publicationFile. Accessed 7 Mar 2011.

32. De Bruin A, Picavet $H$, Nossikov A, editors. Health interview survey. Towards harmonization of methods and instruments. Copenhagen: WHO Regional Office for Europe; 1996.

33. Jepson RG, Harris FM, Platt S, Tannahill C. The effectiveness of interventions to change six health behaviours: a review of reviews. BMC Public Health. 2010;10:538.

34. Lin JS, O'Connor E, Whitlock EP, Beil TL. Behavioral counseling to promote physical activity and a healthful diet to prevent cardiovascular disease in adults: a systematic review for the U. S Preventive Services Task Force Ann Intern Med. 2010;153:736-50.

35. van Dillen SM, van Binsbergen JJ, Koelen MA, Hiddink GJ. Nutrition and physical activity guidance practices in general practice: a critical review. Patient Educ Couns. 2013;90:155-69.

36. Jones $M$, Hockey R, Mishra GD, Dobson A. Visualising and modelling changes in categorical variables in longitudinal studies. BMC Med Res Methodol. 2014;14:32.

37. Arbeitgeberverband Deutscher Fitness- und Gesundheits-Anlagen (DSSV). Membership of fitness studios in Germany from 2003 to 2016 (in millions) [Mitgliederzahl der Fitnessstudios in Deutschland von 2003 bis 2016 (in millionen)]. 2017. https://de.statista.com/statistik/daten/studie/5966/ umfrage/mitglieder-der-deutschen-fitnessclubs/. Accessed 10 Apr 2017.

38. Deutscher Olympischer Sportbund (DOSB), editor. Membership development in sports clubs-surveys and demographic change. [Mitgliederentwicklung in Sportvereinen - Bestandserhebungen und demografischer Wandel]. Frankfurt am Main: DOSB; 2011.

39. Schmitz R, Jordan S, Muters S, Neuhauser H. Population-wide use of behavioural prevention and counselling programmes for lifestyle-related cardiovascular risk factors in Germany. Eur J Prev Cardiol. 2012:19:849-56.

40. Robert Koch Institute (RKI), editor. Facts and figures: Results of the study "German Health Update 2010". Contributions to federal health monitoring. [Daten und Fakten: Ergebnisse der Studie "Gesundheit in Deutschland aktuell 2010". Beiträge zur Gesundheitsberichterstattung des Bundes]. Berlin: RKI; 2012.

41. Hirvensalo $M$, Lintunen T. Life-course perspective for physical activity and sports participation. Eur Rev Aging Phys Act. 2011;8:13-22.

42. Hamer M, Kivimaki M, Steptoe A. Longitudinal patterns in physical activity and sedentary behaviour from mid-life to early old age: a substudy of the Whitehall II cohort. J Epidemiol Community Health. 2012;66:1110-5.

43. Manz K, Mensink GM, Jordan S, Schienkiewitz A, Krug S, Finger J. Predictors of physical activity among older adults in Germany-a nationwide cohort study. BMJ Open 2018;9;8(5):e021940; doi: https://doi.org/10.1136/bmjopen-2018-021940.

44. Pawson R, Greenhalgh T, Harvey G, Walshe K. Realist review-a new method of systematic review designed for complex policy interventions. J Health Serv Res Policy. 2005;10(Suppl 1):21-34.

45. Verheijden MW, Jans MP, Hildebrandt VH, Hopman-Rock M. Rates and determinants of twice participation in a web-based behavior change program for healthy body weight and healthy lifestyle. J Med Internet Res. 2007;9:e1.

46. van Stralen MM, De Vries H, Mudde AN, Bolman C, Lechner L. Determinants of initiation and maintenance of physical activity among older adults: a literature review. Health Psychol Rev. 2009;3:147-207.

47. George ES, Kolt GS, Duncan MJ, Caperchione CM, Mummery WK, Vandelanotte $C$, et al. A review of the effectiveness of physical activity interventions for adult males. Sports Med. 2012;42:281-300.

48. Herens M, Wagemakers A, Vaandrager L, Koelen M. Exploring participant appreciation of group-based principles for action in community-based physical activity programs for socially vulnerable groups in the Netherlands. BMC Public Health. 2015;15:1173.

49. Piirtola M, Kaprio J, Kujala UM, Heikkila K, Koskenvuo M, Svedberg P, et al. Association between education and future leisure-time physical inactivity: a study of Finnish twins over a 35-year follow-up. BMC Public Health. 2016;16:720.

50. Trost SG, Owen N, Bauman AE, Sallis JF, Brown W. Correlates of adults' participation in physical activity: review and update. Med Sci Sports Exerc. 2002;34:1996-2001. 
51. Puhlmann S. Which factors and motives influence people in the adoption and maintenance of sporting activity? Presentation of the current state of research in the form of a literature analysis. Master's thesis. [Welche Faktoren und Motive beeinflussen Menschen bei der Aneignung und Aufrechterhaltung sportlicher Aktivität? Darstellung des aktuellen Forschungsstandes in Form einer Literaturanalyse. Magisterarbeit]. Medizinsche Hochschule Hannover, Medizinsche Hochschule. Hannover. 2002.

52. Stiggelbout M, Hopman-Rock M, Tak E, Lechner L, van Mechelen W. Dropout from exercise programs for seniors: a prospective cohort study. J Aging Phys Act. 2005;13:406-21.

53. Jones H, Millward P, Buraimo B. Adult participation in sport. Analysis of the taking part survey. London: Department for Culture, Media and Sport; 2011.

54. Pedersen BK, Saltin B. Exercise as medicine-evidence for prescribing exercise as therapy in 26 different chronic diseases. Scand J Med Sci Sports. 2015;25(Suppl 3):1-72.

55. Haberman C, Brauer P, Dwyer JJ, Edwards AM. Self-reported health behaviour change in adults: analysis of the Canadian community health survey 4. 1 Chronic Dis Inj Can. 2014;34:248-55.

56. Campbell F, Blank L, Messina J, Day M, Helen BW, Payne N, et al. Physica activity: brief advice for adults in primary care. In: University of Sheffield: National Institute for health and clinical excellence public health intervention guidance; 2012.

57. Orrow G, Kinmonth AL, Sanderson S, Sutton S. Effectiveness of physical activity promotion based in primary care: systematic review and metaanalysis of randomised controlled trials. BMJ. 2012:344:e1389.

58. National Institute for Health and Care Excellence (NICE), editor. Behaviour change: individual approaches. NICE guideline. London: NICE; 2014. p. 37. http://nice.org.uk/guidance/ph49. Accessed 12 Dec 2017.

59. Reis RS, Salvo D, Ogilvie D, Lambert EV, Goenka S, Brownson RC, et al. Scaling up physical activity interventions worldwide: stepping up to larger and smarter approaches to get people moving. Lancet. 2016;388:1337-48.

60. Prevention Act. Law to strengthen health promotion and prevention. [Präventionsgesetz. Gesetz zur Stärkung der Gesundheitsförderung und der Prävention]. In: Bundesgesetzblatt 2015;Teil I Nr 31 vom 24.07; 2015. p. 1368-79.

61. Swann C, Carmona C, Ryan M, Raynor M, Baris E, Dunsdon S, et al. Health systems and health-related behaviour change: a review of primary and secondary evidence. Copenhagen: National Institute for Health and Clinical Excellence; 2010

62. World Health Organization Regional Office for Europe (WHO Europe). Action plan for implementation of the European strategy for the prevention and control of noncommunicable diseases 2012-2016. Copenhagen: WHO Europe. p. 2012.

63. Brug J, van der Ploeg HP, Loyen A, Ahrens W, Allais O, Andersen LF, et al. Determinants of diet and physical activity (DEDIPAC): a summary of findings. Int J Behav Nutr Phys Act. 2017;14:150.

Ready to submit your research? Choose BMC and benefit from:

- fast, convenient online submission

- thorough peer review by experienced researchers in your field

- rapid publication on acceptance

- support for research data, including large and complex data types

- gold Open Access which fosters wider collaboration and increased citations

- maximum visibility for your research: over $100 \mathrm{M}$ website views per year

At $\mathrm{BMC}$, research is always in progress.

Learn more biomedcentral.com/submissions 